\title{
SMSLEFA: An alternative synergistic multilayered analysis of students' learning engagement in EFL context
}

\author{
Didi Suherdi \\ English Language Education Department, Faculty of Language and Literature, Universitas Pendidikan Indonesia, \\ Bandung, West Java, Indonesia
}

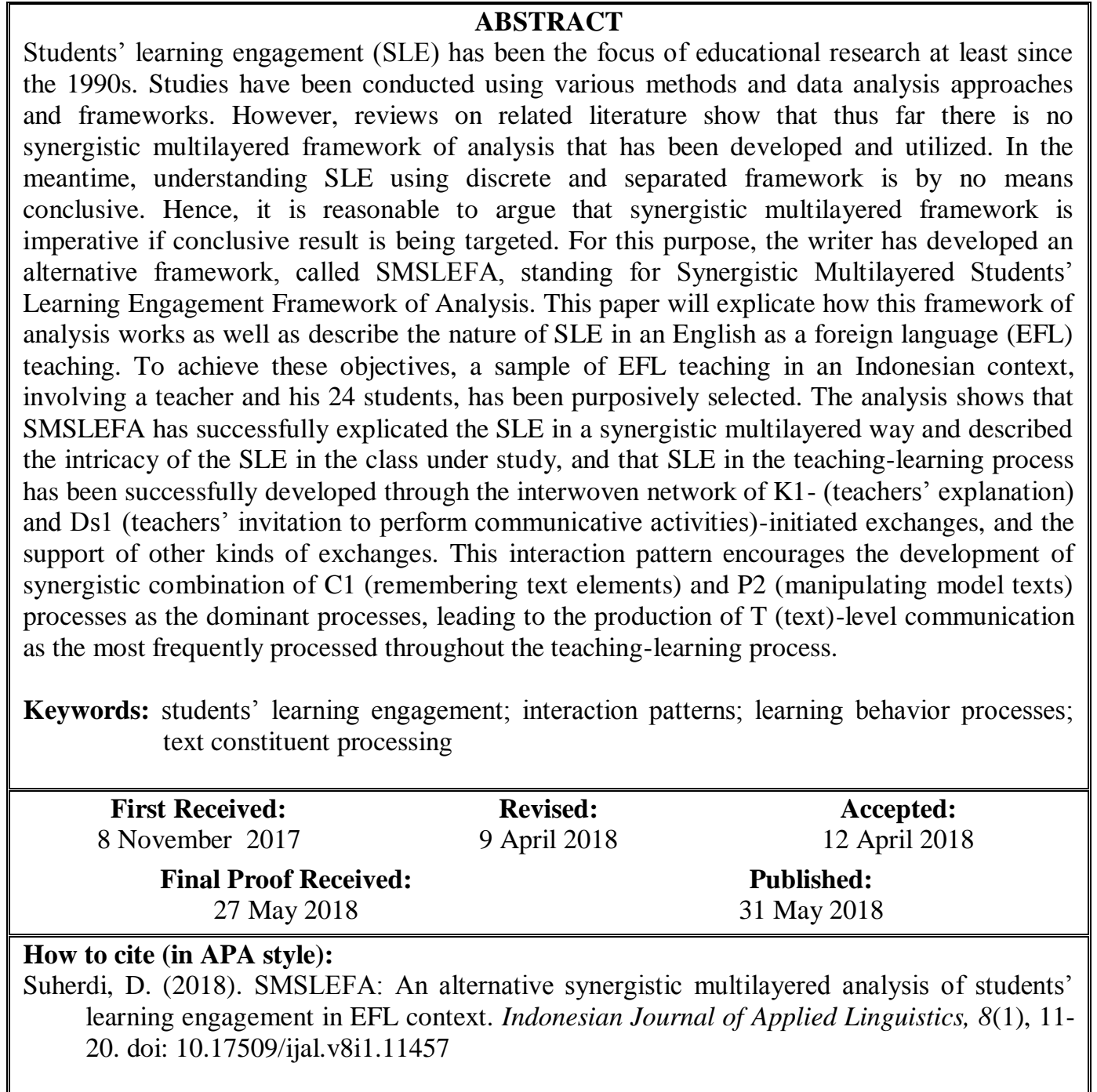

\section{INTRODUCTION}

Students' learning engagement (SLE) has been defined in many different ways. Some are very general, and some are very specific. In the broadest sense, it covers any engagement in the classrooms and out-ofclassrooms, even out-of-school contexts. As evident in the variability of the aforementioned research scope and foci, it is related to the variability of the ways in which SLE is defined. For the purpose of this study, following
Kuh (2009), engagement is considered to represent "the time and effort students devote to activities that are empirically linked to desired outcomes of college and what institutions do to induce students to participate in these activities" (p. 623). To be specific, engagement in this study will be investigated in terms of the time and effort teachers and students devote to achieve the expected learning outcomes as indicated by students' roles and contribution in classroom interactions,

\footnotetext{
* Corresponding author:

Email: suherdi_d@upi.edu
} 
learning behavior characteristics, and texts used in classroom communication.

There has been an increasingly growing interest in studying students' learning engagement (SLE) in recent research literature (Trowler, 2010; Henrie, Bodily, Manwaring, \& Graham, 2015; Ko, Park, Yu, Kim, \& Kim, 2016). Various topics have been the foci of different research projects carried out in the last fifteen years (see e.g. Zhao \& Kuh, 2004; Carini, Kuh, \& Kelin, 2006; Crook \& Mitchell, 2012; Angelaina \& Jimoyiannis, 2012; Boss, Angell, \& Tewell, 2015; Tan \& Hew, 2016). Zhao and Kuh (2004) examined the relationships between participation in learning communities and student engagement in a range of educationally purposeful activities of first-year and senior students from 365 4-year institutions; Carini, Kuh, and Kelin (2006) examined the extent to which student engagement is associated with experimental and traditional measures of academic performance, whether the relationships between engagement and academic performance are conditional, and whether institutions differ in terms of their ability to convert student engagement into academic performance; Crook and Mitchell (2012) investigated how SLE was realized in various learning spaces; Angelaina and Jimoyiannis (2012) investigated students' participation and learning presence in an educational blog implemented as a crossthematic inquiry activity; Boss, Angell, and Tewell (2015) assessed the success of Amazing Library Race in developing SLE in library orientation sessions; and Tan and Hew (2016) examined how the use of meaningful gamification affects student learning, engagement, and affective outcomes in a short, 3-day blended learning research methods class using a combination of experimental and qualitative research methods.

SLE, as indicated earlier, has been studied in different ways and perspectives. To have a comprehensive idea of the previous research coverage, Trowler's (2010) review has been chosen to serve as a reference for some relevant parts of the current study. Trowler managed to map the typologies of engagement, the responsibilities, and the targets, purpose, and parties involved, effects, influencing factors, as well as the strategies for the development of engagement. Based on the map, this research falls in the categories of those of small scaled, focused on teaching-learning processes, and intended to improve teaching-learning qualities. Hence, in terms of those aspects, there is nothing new in this research. However, in terms of the source of data and the instrument of data collection and analysis, this research is unequivocally critical, at least for the following reasons. First, the source of the data used in this research is the classroom discourse, i.e. the language used by teachers and students in a specific context, in this case in an Indonesian EFL context. As stated by Stubb (1976, p. 68), "ultimately, the classroom dialogue between teachers and pupils $i s$ the educational process, or, at least, the major part of it". He added, "Other factors such as children's language, IQ, social class and home background, however important they may be as contributing factors, are nevertheless external, background influences" (Stubb, 1976, p. 68).

Second, the analysis system used is discourse analysis, as Chaudron (1988a, p. 15) highlighted, "The discourse analysis approach tends to describe each new shift in function, even within the segments of the discourse, whether utterances or turns. Also discourse analysis hierarchically groups the lower scales into the higher ones." In the meantime, other approaches to analysis, as Chaudron identified, "cannot account for such hierarchical structure in classroom interaction" (Chaudron, 1988a, p. 15).

Third, the data analysis framework, SMSLEFA (to be elaborated later in the Method section), is developed based on Hallidayan (Halliday, 1961, 1975, 1985, 1994, 2010) systemic functional linguistic meta-functions (ideational, interpersonal, and textual). As highlighted by Matthiessen (2012, p. 438):

As the theoretical and descriptive power and potential of
SFL continued to grow, researchers were able to address
problems in a growing number of areas outside
linguistics in the 1960s and the 1970s - including
education (e.g. Halliday, McIntosh \& Strevens, 1964),
translation (e.g. Catford, 1965), and computation (e.g.
Winograd, 1972; Davey, 1978). This ability to engage
with problems that lie outside linguistics itself is in fact
related to the different disciplinary currents that have
informed and become part of SFL, including
anthropology, anthropological linguistics, sociology,
educational theory, neuroscience, computational
linguistics, and AI. Thus SFL has always been
developed in dialogue with other disciplines; it has
always been "permeable", as Halliday (1985: 6) puts it:
"a salient feature in the evolution of systemic theory: its
permeability from outside ... systemic theory has never
been walled in by disciplinary boundaries".

The fact that SMSLEFA is developed based on SFL (Systemic Functional Linguistics) principles, especially the concepts of language meta-functions, as will be elaborated later, lends itself to powerful, synergistic, comprehensive, and united multilayered analysis. The writer's review of Trowler's (2010) work did not lead him to anything related to the use of discourse analysis, systemic functional linguistics, or classroom discourse. This convinces the writer that studying SLE in this perspective is not only interesting but also critical for the search of the nature of SLE, especially from the classroom communication perspective.

In Asia contexts, including that of Indonesia, the significance of this study is also confirmed. The writer's review of the Journal of Asia TEFL and TEFLIN Journal in the last five years shows that research on this area has not been established. From those volumes, there are only three articles written on this topic in the former and one in the latter. To make it worse, no article in the journals is written using the term engagement. To be specific, two articles use interaction, one uses involvement, and the other uses the term participation. Those terms are indeed related to, but, as Trowler 
(2010, p. 5) identified, narrower than "engagement." The four articles are the works of Day (2015), Wang (2017), Utami, Saukah, Cahyono, and Rachmajanti (2017), and Suryati (2015).

Day's (2015) work is an attempt to determine if an activity involving primary and secondary responders would help the 15 subjects of the study participate in discussion of a particular student's presentation. Wang (2017) ascertained the relationship between students' perception and students' communication motivation and students' communication apprehension. In the meantime, Utami et al. (2017) examined levels of involvement in teachers' CPD (Continuous Professional Development) in the contexts of portfolio-based teachers' certification program in Indonesia.

In the meantime, Suryati's (2015) was concerned with classroom interaction strategies employed by English teachers at lower secondary schools. In terms of the data analysis framework, i.e. discourse analysis, it is related to the current study. She employed Sinclair and Coulthard's (1975) IRF pattern analysis, which serves as the starting point of SMSLEFA's development history.

In TEFLIN Journal, there are two articles that, to some extent, are related to the current study, i.e. that of Emilia and Hamied (2015) and that of Tulung (2013). Emilia and Hamied (2015) examined how systemic functional linguistic genre pedagogy (SFLGP) can help develop students' ability in English and their perceptions about the teaching program. Meanwhile, Tulung's (2013) was concerned with oral discourse produced by medical students, including L2 and L1, in relation to communicative tasks and the EFL contexts. The former has to do with the current study in the way it employs SFL as its basis; however, it has nothing to do with SLE. As for Tulung's, it concerns oral discourse as the product of certain communicative tasks in EFL contexts. It says nothing about SLE.

To sum up, it is clear that the studies available are still far from being well-established if they are to be included in the studies of SLE. Both the coverage and the depth are by no means exhaustive. Hence, studying SLE by the way of revealing the qualities of studentsteachers, and students-students interaction patterns, students learning behavior, and students' language in synergetic ways is imperative.

\section{METHOD}

\section{Contexts and Participants}

The study utilized a sample of a teaching program that has been purposively selected. The class consists of an Indonesian senior high school teacher and 24 students involved in teaching-learning processes dealing with talking about news items in the context of genre-based teaching English as a foreign language in Indonesia.

\section{Data Collection Instrument}

The data were collected through a series of activities, starting from recording teaching-learning processes, observation, and field note taking. The recording was carried out to document the teaching programs to enable analysts to get the details of each shift and activity in the teaching-learning processes under study. In the meantime, the other two instruments (observation and field note) were only used to support the primary data, i.e. the recording. Observation was used to help understand the data of the real teaching contexts; while field note was used to record important incidents during the teaching-learning processes so that SMSLEFA can be used properly in analyzing classroom discourse recorded.

\section{Data Analysis}

The data collected were then analyzed according to their nature and function. The main data, i.e. classroom discourse as recorded in the teaching-learning process recordings were then analyzed using SMSLEFA (Synergetic Multilayered Students' Learning Engagement Framework of Analysis). Meanwhile, the other data were used to complement the main data and were analyzed qualitatively in accordance with the effort of making the analysis exhaustive.

To give clearer ideas on the data analysis process, especially through SMSLEFA, concise explanation will be presented in the rest of this section. SMSLEFA was developed based on systemic functional linguistic metafunctions. Like language meta-functions, SMSLEFA consists of three layers, i.e. learning interaction (LI), learning behavior (LB), and learning texts (LT) or the language used in the classroom teaching.

\section{Analyzing LI}

As SFL analysts take interpersonal meta-function as the function that deals with the social and power relations among language users (See, e.g. Halliday \& Hassan, 1985; Butt, Fahey, Spinks, \& Yallop, 1995), SMSLEFA takes LI as the layer that helps manifest the role relationships among interactants in classroom discourses. To be specific, this layer is concerned with the power relationships between teachers and students, and students and students. In analyzing this layer, the writer adopts systemiotic approach to classroom discourse analysis, which is developed based on the work of Sinclair and Coulthard (1975), Berry (1981a, b, c, 2014), Martin (1985), and Ventola (1987, 1988a, 1988b). To give readers clear ideas of the framework of analysis in this approach, a concise, yet comprehensive explanation will be presented in this section. The explanation will be presented in a chronological order, from Sinclair and Coulthard (1975) to Ventola (1988a, 1988b).

One of the seminal contributions of Sinclair and Coulthard's (1975) work to discourse analysis is IRF pattern of exchanges, emerging in their data. This has helped many researchers analyze classroom discourses (see e.g. Suryati, 2015). However, some researchers, among others, Berry (1981a, 1981b), found that this pattern could not match more complex classroom discourses, in which exchanges go beyond teachers' 
initiation, students' response, and teachers' follow-up (IRF). As an alternative, Berry proposes a multilayered framework of analysis based on language metafunctions developed by Halliday and his disciples and followers (see e.g. Martin, 1985; Matthiessen, 2012). Instead of IRF, Berry proposed a different system of exchange network and representation as Dk1 $\wedge^{\wedge} \mathrm{K} 2{ }^{\wedge} \mathrm{K} 1$ $\wedge \mathrm{K} 2 \mathrm{f} \wedge \mathrm{K} 1 \mathrm{f}$, in which if $\mathrm{K}$ stands for knowledge or knower, 1 for primary, and 2 for secondary and $\mathrm{D}$ for delaying and ${ }^{\wedge}$ for followed by, the representation may be read as the teacher may sometimes delay his/her role as the primary knower in the interaction (Dk1), or ask question rather than giving/transferring information. The question is a testing one, not a genuine one.

The second move is $\mathrm{K} 2$ which may be read as "secondary knower's response/initiation" to the question asked; and $\mathrm{K} 1$ as "primary knower delivers/confirms the information". In a simpler word, the teacher may then confirm by saying "OK/Right/Excellent" or other kinds of semiotic signs of stamping the "knowledge". In the meantime, K2f is a follow-up or comment given by secondary knower, and $\mathrm{K} 1 \mathrm{f}$ is a follow-up for or a comment by primary knower on secondary follow-up or comment. The whole exchange may be exemplified by the following teacherstudents dialog:

\section{Example 1 \\ Dk1 T: S3, what does Dk1 represent? \\ K2 S3: A teacher question? [doubtful] \\ K1 T: Good. That's right. \\ K2f S3: Oh. \\ K1f T: Yes. Right.}

Martin's (1985) work help improve Berry's system by adding to it ways of identifying dynamic moves. Hence, now there are two move systems that may work together in an exchange. Dynamic moves differ from synoptic ones in that they can only operate when there is a problem in the flow of synoptic moves. Example 2 may illustrate these phenomena.

\section{Example 2}

$\begin{array}{lll}\text { Dk1 } & \text { T: } & \text { S3, what does Dk1 represent? } \\ \text { r0 } & \text { S3: } & {[\ldots 4 \ldots]} \\ \text { Clue } & \text { T: } & \text { Is it a question or a statement? } \\ \text { K2 } & \text { S3: } & \text { A question } \\ \text { Rclf } & \text { T: } & \text { Whose question? } \\ \text { Clf } & \text { S3: } & \text { Teacher } \\ \text { K1 } & \text { T: } & \text { That's right. }\end{array}$

Different from the dialog in Example 1, in Example 2 we see not only synoptic (Dk1, K2, and K1), but also dynamic moves (r0, clue, rclf, and clf). In the meantime, Ventola's (1987) work helps improve this system by incorporating the notions of unit move and unit move complex. In many cases, interactants repeat certain expression in a single whole, without pause. To give readers a clear idea, see Example 3.
The exchange is now far more complex than that in Example 1. In Example 3, we have four successive questions (hence, $4 \mathrm{Dk} 1 \mathrm{~s}$ ). However, different from those in Example 2, they are in a single whole. No pause exists among the questions. In other words, they are in a single complex, or they are not four unit moves, but rather one single unit move complex.

\begin{tabular}{|c|c|c|c|}
\hline \multicolumn{4}{|c|}{ Example 3} \\
\hline Dk1 & 1 & $\mathrm{~T}:$ & S3, what does Dk1 represent? \\
\hline Dk1 & $=2$ & & What does Dk1 represent? \\
\hline Dk1 & +3 & & $\begin{array}{l}\text { Sometimes teachers do a DK1 } \\
\text { rather than a K1 }\end{array}$ \\
\hline Dk1 & $\mathrm{x} 4$ & & $\begin{array}{l}\text { So, what is DK1 in our daily } \\
\text { conversation? }\end{array}$ \\
\hline r0 & & S3: & {$[\ldots 4 \ldots]$} \\
\hline Clue & & $\mathrm{T}:$ & Is it a question or a statement? \\
\hline $\mathrm{K} 2$ & & S3: & A question \\
\hline Rclf & & $\mathrm{T}:$ & Whose question? \\
\hline Clf & & S3: & Teacher \\
\hline $\mathrm{K} 1$ & & $\mathrm{~T}:$ & That's right. \\
\hline
\end{tabular}

Based on Berry's ESN, standing for Exchange Network System (Ventola, 1988b, p. 54) and its Realization Statement (Ventola, 1988b, p. 98) and apart from those of the exchanges presented in Examples 1, 2, and 3 , there are some possible acceptable patterns of exchanges of knowledge $(\mathrm{K})$ in classroom discourse, including:

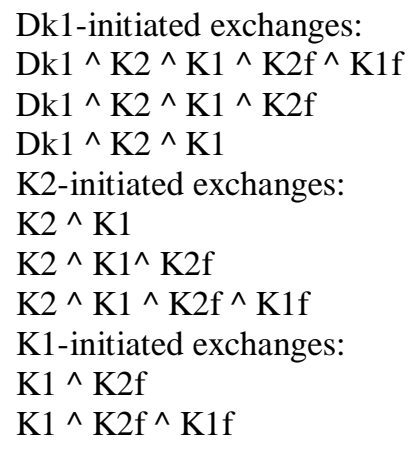

In actions- and skills-oriented exchanges, similar patterns may be found in classroom discourses with different labels, A for action and $\mathrm{S}$ for skills. For extensive elaboration of these patterns, see Suherdi (2009).

In their articles, Berry (1981a, 1981b, and 2014), Martin (1985), and Ventola (1987, 1988a, 1988b) used natural conversation samples to exemplify their ideas. The writer managed to interweave all these phases of the development and adapt the framework of analysis to suit classroom discourse. For more detailed and elaborate explanation, readers may read Love and Suherdi (1996) and Suherdi (1994, 2009).

\section{Analyzing LB}

In SFL, ideational metafunction is concerned with human experience and in language it is realized through transitivity system (see, e.g. Halliday, 2007). Analogous 
to the system, the second layer, LB, is concerned with the learning behavior performed by the students as evident in the classroom discourse. In analyzing LB, the activity carried out in each will be examined and fitted to Bloom's (Kratwhol, 2002) cognitive domain taxonomy and affective domain taxonomy (Kratwhol, Bloom, \& Maisa, 1973), and Dave's (1975) psychomotor domain taxonomy.

As this layer is synergetically related to the first layer, its analysis rests on the result of LI's analysis. Based on the label of the moves, the category of an exchange can then be determined, whether it is a $\mathrm{K}$ oriented, A-oriented, or an S-oriented. This identified category leads to students' learning behavior processes. $\mathrm{K}$ corresponds to cognitive (C), A, to some extent informs students' affective (A), and S corresponds to Psychomotor (P) behaviors. Cognitive domain includes remembering, understanding, applying, analyzing, evaluating, and creating (Kratwhol, 2002); affective domain includes receiving phenomena, responding to phenomena, valuing, organizing, and characterizing (Kratwhol, Bloom, \& Maisa, 1973); and psychomotor domain includes imitating, manipulating, précising, articulating, and naturalizing (Dave, 1975).

To get more detailed idea of the learning behavior that may be found in real classroom practice, see Figure 1.

As shown in Figure 1, in cognitive domain, there are six levels of learning behavior (remembering, understanding, applying, analyzing, evaluating, and creating), symbolized by $\mathrm{C}$, standing for cognitive, followed by numbers ( 1 to 6 ), indicating the levels of complexity of the processes involved in the behavior.

In the meantime, Affective Domain consists of five behaviors. The detailed list of the behavior can be seen in Figure 2.

Figure 2 presents five levels of affective domain of learning behavior, i.e. receiving, responding, valuing, organizing, and characterizing.

Last, but not least, Psychomotor Domain also includes five levels of complexity. To get a detailed picture, see Figure 3.

As shown in the figure, psychomotor domain covers imitating $(\mathrm{P} 1)$, manipulating $(\mathrm{P} 2)$, précising $(\mathrm{P} 3)$, articulating (P4), and naturalizing (P5).

\begin{tabular}{|lcl|}
\hline Behavior & Symbol & Specific Behavior \\
Remembering & C1 & Recognize, recall \\
Understanding & C2 & Interpret, exemplify, classify, summarize, compare, infer, explain, \\
Applying & C3 & Execute, implement \\
Analyzing & C4 & Differentiate, organize, attribute \\
Evaluating & C5 & Check, critique \\
Creating & C6 & Generate, plan, produce \\
\hline
\end{tabular}

Figure 1 Cognitive Domain

\begin{tabular}{|lcl|}
\hline Behavior & Symbol & Specific Behavior \\
Receiving & A1 & Differentiate, accept, listen (for), respond to. \\
Responding & A2 & Comply with, follow, commend, volunteer, acclaim \\
Valuing & A3 & Increase measured proficiency in, relinquish, subsidize, support, debate \\
Organizing & A4 & Discuss, theorize, formulate, balance, examine \\
Characterizing & A5 & Revise, require, be rated high in the value, avoid, resist, manage, resolve \\
\hline
\end{tabular}

Figure 2 Affective Domain

\begin{tabular}{|lcl|}
\hline Behavior & Symbol & Specific Behavior \\
Imitating & P1 & Copy, follow, mimic, repeat, replicate, reproduce, trace \\
Manipulating & P2 & Act, build, execute, perform \\
Précising & P3 & Calibrate, demonstrate, master, perfectionism \\
Articulating & P4 & Adapt, construct, combine, create, customize, modify, formulate \\
Naturalizing & P5 & Create, design, develop, invent, manage, naturally \\
\hline
\end{tabular}

Figure 3 Psychomotor Domain

\section{Analyzing LT}

In SFL, textual metafunction is concerned with the creation of text (See, e.g. Halliday, 1981). In analyzing LT, SMSLEFA views teacher's and students' texts in a Theme/Rheme or Given/New perspective. This means that the teacher's texts determine or lead students' ones. When teachers expect one word answers, students will normally provide one word answers, one phrase with one phrase, sentences with sentences, and texts with texts. In other words, in the analysis, LT will be examined in terms of text constituents (syllables, words, phrases, sentences, or texts).
To sum up, there are two data analysis techniques used in this study, i.e. SMSLEFA used to analyze the discourse recorded from the purposively selected classrooms, and qualitative data analysis to deal with data from field notes and FGD notes.

\section{FINDINGS AND DISCUSSION \\ Findings}

Interaction patterns

The first layer, LI, as stated earlier, is analyzed using systemiotic approach to classroom discourse analysis. The data in the lesson have been summarized in Table 1. 
From Table 1, we can see that S-oriented exchanges form the majority $(53.58 \%)$ of the exchanges in the lesson. This is also indicated by the time devoted to this kind of exchanges, which is far above that devoted to K-oriented and A-oriented. This indicates that the teacher's main concern was students' skills in talking about news items. To establish these skills, the teacher utilized explanations, illustrations, and examples prior to skill-oriented exercises. The fact that Ds1 is dominant indicates that students performed their communicative skills as commanded by the teacher. To illustrate this case, see Example 4.

Table 1 Data of students-teacher interaction patterns

\begin{tabular}{lcrrr}
\hline & $\begin{array}{c}\text { Exchange } \\
\text { Type }\end{array}$ & Number & \multicolumn{1}{c}{$\%$} & Note \\
\hline \multirow{5}{*}{ K-oriented } & K1-initiated & 30 & 21.43 & \\
& K2-initiated & 2 & 1.42 & \\
& Dk1-initiated & 23 & 16.43 & \\
& Sub-total & 55 & 39.28 & \\
& & & & \\
S-Oriented & S1-initiated & 9 & 6.44 & \\
& S2-initiated & 0 & 0.00 & Lowest \\
& Ds1-initiated & 66 & 47.14 & Highest \\
& Sub-total & 75 & 53.58 & \\
& & & & \\
& A1-initiated & 3 & 2.14 & \\
& A2-initiated & 1 & 0.71 & \\
& Da1-initiated & 6 & 4.29 & \\
& Sub-total & 10 & 7.14 & \\
& & 140 & 100.00 & \\
\hline
\end{tabular}

\begin{tabular}{|c|c|c|c|}
\hline \multicolumn{4}{|c|}{ Example 4} \\
\hline & \multicolumn{3}{|c|}{$\begin{array}{c}\text { Example } 4 \\
47 \text { Ds } 1\end{array}$} \\
\hline & \multirow[t]{8}{*}{$\mathrm{S} 2$} & \multirow[t]{8}{*}{ S5 + S6 } & $\begin{array}{l}\text { (S5 and S6 are ready to have a } \\
\text { conversation) }\end{array}$ \\
\hline & & & $\begin{array}{l}\text { S6: Hi. Good morning, how are } \\
\text { you? }\end{array}$ \\
\hline & & & $\begin{array}{l}\text { S5: Hi. I'm fine thank you, how } \\
\text { about you? }\end{array}$ \\
\hline & & & $\begin{array}{l}\text { S6: I'm fine. Did you watch } \\
\text { Liputan } 6 \text { last night? }\end{array}$ \\
\hline & & & S5: No, why? \\
\hline & & & S6: We have another landslide \\
\hline & & & S5: Landslide again? \\
\hline & & & S6: YES \\
\hline & \multirow{3}{*}{$\begin{array}{l}\text { S1 } \\
\text { S2f }\end{array}$} & \multirow{3}{*}{$\begin{array}{l}\mathrm{T} \\
\mathrm{Ss}\end{array}$} & Very good \\
\hline & & & Yeeeeeeeeeeeeeee \\
\hline & & & $\begin{array}{l}\begin{array}{l}\text { students give them } a \\
\text { applause) }\end{array}\end{array}$ \\
\hline
\end{tabular}

Example 4, which is Exchange 47 in the lesson, illustrates how Ds1-initiated exchanges are performed in the lesson. In the example, two students nominated to perform the dialog learnt did their parts, starting with the teacher's invitation (Ds1), followed by students' performance (S2) and teacher's evaluation (S1), and ended up with other students' appreciation (S2f). This kind of exchange, as stated earlier, is the most dominant one in this lesson.

This kind of exchange is normally preceded by an S1-initiated exchange as a way of presenting the model, usually carried out by the teacher. See Example 5. The Indonesian texts (in italic) used by the teacher has been retained in the example to guarantee the authenticity of the texts. Translation and clarification will then be presented in discussing the exchange.

Example 5

$$
\begin{array}{rllll}
32 & \mathrm{~S} 1 & 1 & \mathrm{~T} & \begin{array}{l}
\text { Tidak dipotong "saya-makan-ikan- } \\
\text { asin". }
\end{array} \\
\mathrm{S} 1=2 & & \begin{array}{l}
\text { Tidak pernah dipotong-potong... } \\
\mathrm{S} 1
\end{array}=3 & & \text { "Did you watch Liputan } 6 \text { last night?" } \\
\mathrm{S} 1 & +4 & \text { "Did you watch Liputan } 6 \text { last night?" } \\
& & \text { "No, why?" }
\end{array}
$$

Prior to Exchange 47, in Example 5, which is Exchange 32, the teacher was trying to model the way students were expected to pronounce the expressions in the conversation. He said 'tidak dipotong' which literally means 'do not segment the pronunciation' like if they pronounce the Indonesian sentence 'sayamakanikanasin' which is written as 'saya makan ikan asin' in written form. He was trying his best to lead students to excellent performance. This is indicated by his use of unit move complex, consisting of four clauses, two of which were repetitions of the preceding clauses (symbolized by $=$ in $=2$ and $=3$ ), and one was an addition for the information in the preceding clause (symbolized by + in +4 ).

What K-oriented exchange shows is also pedagogically interesting. The fact that the number of K1-initiated is dominant, larger than that of Dk1- and $\mathrm{K} 2$-oriented exchanges, is consistent with the role of the lesson as the one that lays the foundation of students' ability in understanding and making the best use of news items in their daily communication. The teacher was consistently doing his best in explaining the ways students were expected to develop their ability in talking about news that they hear or watch in their daily life.

Last, the data of A-oriented exchanges show that the teacher used very little non-verbal exchanges in managing the class teaching activities, like 'go back to your seats', 'work in pair', etc. With this policy, he could concentrate on developing students' communicative skills.

\section{Learning behavior}

As stated earlier, LB will be analyzed using Bloom's taxonomy as the basis of analysis. The result of the analysis is summarized in Table 2 .

Table 2 tells us that the number of P-processes which outweighs the other two processes is consistent with the dominance of S-oriented exchanges in the LI. In other words, the teacher puts emphasis on communicative skills development, which is psychomotor in nature, with the help of cognitive and affective processes. The fact that $\mathrm{P} 3$, précising, is the most dominance in this lesson may, again, indicate the teacher's focus on helping students develop high standard of communicative competence. P1 and P2, in this context, were developed to lay the foundations for the higher level of communicative skills, P3, P4, and P5. Unfortunately, P4 and P5 could not be developed in this lesson because the foundation was not yet firm. To illustrate the finding, see Example 6. 
Table 2 Learning behaviors developed in the teaching-learning processes

\begin{tabular}{rlrrr}
\hline & Processes / Exchange type & Number & \multicolumn{1}{c}{$\%$} & Note \\
\hline & Remembering (C1) & 48 & 24.24 & \\
& Understanding (C2) & 15 & 7.58 & \\
Cognitive & Applying (C3) & 1 & 0.51 & \\
Process & Analyzing (C4) & 0 & 0.00 & \\
& Evaluating (C5) & 0 & 0.00 & \\
& Creating (C6) & 0 & 0.00 & \\
& Sub-total & 64 & 32.32 & \\
& Receiving (A1) & 23 & 11.62 & \\
& Responding (A2) & 29 & 14.64 & \\
Affective & Valuing (A3) & 3 & 1.51 & \\
Processes & Organizing (A4) & 0 & 0.00 & \\
& Characterizing (A5) & 0 & 0.00 & \\
& Sub-total & 55 & 27.78 & \\
& Imitating (P1) & & & \\
& Manipulating (P2) & 12 & 6.06 & \\
& Précising (P3) & 18 & 9.09 & \\
Psychomotor & Articulating (P4) & 49 & 24.75 & Highest \\
Processes & Naturalizing (P5) & 0 & 0.00 & \\
& Sub-total & 0 & 0.00 & \\
& Total & 79 & 39.89 & \\
\hline
\end{tabular}

In this exchange, the teacher asked the students to work on the segment of the conversation in pairs (kembali lagi ke pasangan masing-masing, meaning "go back to your partner") in the hope that the students could get correct and appropriate skills in communicating the ideas contained in the segment. In other parts of the lesson, the teacher nominated students based on the alphabetic order of the first letter of their names according to the number of the order which corresponded to the date of the day, the month, or the year (e.g. OK. ... I want to know 'who is number 8 on the list', corresponding to August, the month).

\section{Example 6}

$$
\begin{aligned}
& \begin{array}{lll}
8 & 3 & \text { ok, } \\
& & \text { go... }
\end{array} \\
& \text { kembali lagi ke pasangan masing- } \\
& \text { masing.... } \\
& \text { Minutes 42:20-44:56: (students work in } \\
& \mathrm{s} \text { pairs. There are } 12 \text { pairs working on }
\end{aligned}
$$

In the meantime, A-processes were used to develop sustainable interest and motivation in mastering the skills. Example 7 may illustrate this.
Example 7

$$
\begin{aligned}
16 \text { A1 T } & \text { Ya...oke } \\
& \text { So... (The teacher writes on the board the } \\
& \text { word 'equipment') ... biasanya untuk } \\
& \text { longsor, kita menggunakan kata } \\
& \text { "equipment..."... }
\end{aligned}
$$

Last, but not least, the C-processes were devoted to build the factual, conceptual, and procedural as well as metacognitive knowledge of talking about news items, in this case about the landslide in Bali. To illustrate, see again Example 7. In the example, the teacher was trying to build the vocabulary, in this case the word 'buried' (C1), required to understand and develop talks on landslide.

In conjunction with the third layer, i.e. $\mathrm{LT}$, the data collected may be presented in Table 3 .

Table 3 Data of texts produced in the teaching-learning processes text constituents

\begin{tabular}{lcrrr}
\hline $\begin{array}{c}\text { Constituent } \\
\text { Level }\end{array}$ & Resources & Number & \multicolumn{1}{c}{$\%$} & Note \\
\hline Texts (T) & Multi & 6 & 4.17 & \\
& Mono & 103 & 71.53 & Highest \\
Sentences (S) & Multi & 2 & 7.58 & \\
& Mono & 3 & 2.08 & \\
Phrases (P) & Multi & 0 & 0.00 & \\
& Mono & 14 & 9.72 & \\
Words (W) & Multi & 9 & 6.25 & \\
& Mono & 7 & 4.86 & \\
Syllables (L) & Multi & 0 & 0.00 & \\
Total & Mono & 0 & 0.00 & \\
\hline
\end{tabular}

As shown in the table, the LTs produced by both the teachers and the students in the lesson are categorized into texts $(\mathrm{T})$, sentence $(\mathrm{S})$, phrases $(\mathrm{P})$, words (W), and syllables, to avoid confusion with $\mathrm{S}$ for sentences). Each of the categories is divided into multimodal or multi-semiotic (M) and Mono-modal or 
mono-semiotic (Suherdi, 2017), depending on whether or not they involve more than one mode or semiotic resource. Here are some facts of LTs:

1. Monomodal and/or monosemiotic texts form the majority of LTs in the lesson up to 103 $(71.53 \%)$.

2. There are 6 multimodal and/or multi-semiotic texts (MT), 2 sentences, and 9 words.

3. No syllable or multimodal phrase is shown in the table.

The fact that mono-modal texts were produced in a great number in the lesson indicates that the teacher put texts as the basis of communicative competence development. In the meantime, other categories, including sentences, phrases, words, and even multimodal texts were utilized in his teaching to help develop texts mastery.

\section{Discussion}

The patterns of SLE emerging in the data indicate the principles employed and the stage being carried out by the teacher, i.e. genre-based teaching (See, e.g. Rivera, 2012; Payaprom, 2012; Martin, 2015). As the stage carried out is the initial one, i.e. modeling, K1-initiated exchanges, which were developed to help the students get acquainted with the texts (Cf. Emilia, 2005; Malekie \& Moghaddam, 2017), turned out to be the most dominant one in the lesson. The teacher successfully combined this with Ds1-initiated exchanges to engage students in the process of developing high standard of communicative skills. He also managed to make the best use of other patterns to support this. He used Dk1initiated exchanges to engage students in watching and understanding the model, S1-initiated to present the model, and A-oriented exchanges to manage the class.

The interaction developed brings about conducive conditions for the development of processes required to establish the skills targeted at this stage, i.e. acquiring the model of talking about news items. The dominance of $\mathrm{C} 1$ is consistent with the nature of modeling. However, the dominance of $\mathrm{P} 2$ is rather surprising. P1 is more consistent with this stage. The fact that the class is composed of the best students in the schools may be accounted for this phenomenon. Hence, it is understandable if $\mathrm{T}$ is the most frequently produced LT in the lesson.

The way the teacher interwove all patterns of interaction, including the absence of S2-initiated exchanges signify the primacy of teacher's role as students' learning manager in engaging students in classroom activities (See also Marzano, Marzano, \& Pickering, 2003), especially in foreign language teaching, and the significance of scaffolding (See also Yelland \& Masters, 2007; Walqui, 2006; Van de Pol, Volman, \& Beishuizen, 2010) in developing communicative competence. Furthermore, interweaving K1- and Ds1-initiated exchanges allowed him to lay firm foundations for students' performance. This is evident in students' texts production which is far larger in number than sentences, phrases, and words which are common in traditional teaching-learning processes (Feez \& Joyce, 2002; Byram, 2004). Such kind of success may be attributed to the successes that follow. In addition, this may also be accounted for the students' sustained motivation and engagement throughout the teaching-learning process (Park et al., 2014).

The absence of higher order thinking processes and voluntary initiative in classroom communication in the part of the students may be due to the nature of modeling stage in any foreign language teaching, especially in Indonesian contexts. This strategy has intentionally been chosen to guarantee that the students would be served with comprehensible input as well as output which is, in Krashen's $(1981,1982)$ term, within their $i+1$.

\section{CONCLUSION}

This paper has been successful in demonstrating how SMSLEFA analyzes SLE synergistically and in describing SLE in an Indonesian genre-based teaching. As for the first objective, it has been shown that the data have been analyzed in three synergistic and integrated layers. The analysis of LI is used as the basis for the analyses of LB and LT. In the meantime, the analysis of LB helps elaborate the results of LI and LT analyses. Likewise, the result of LT analysis sheds light on the results of LI and LB analyses.

In conjunction with the second objective, the SLE has been described in such a way so that it is clear that the SLE patterns indicate the belief that the teacher holds about teaching and language teaching as well as communicative competence. In addition, the SLE in the teaching program is well sustained and helps the teacher and students achieve their teaching and learning objective targeted for the stage of teaching under investigation. To sum up, SMSLEFA has fulfilled its function well, and the SLE has been synergistically described.

Based on the conclusions, some further research need to be conducted both in relation to the development of SMSLEFA so that it can further elaborate complex exchanges that represent more complex conversations and in relation to revealing the intricacy of classroom dialogs in different settings and contexts of language teaching. All those efforts may further enlighten the classroom research, especially in the contexts of the teaching of languages in first, second, and foreign language perspectives.

\section{REFERENCES}

Angelaina, S., \& Jimoyiannis, A. (2012). Analysing students' engagement and learning presence in an educational blog community. Educational Media International, 49(3), 183-200.

Berry, M. (1981a). Systemic linguistics and discourse analysis: a multi-layered approach to exchange structure. In M.Coulthard \& M.Montgomery (eds), 
Studies in Discourse Analysis (pp. 120-45.).

London: Routledge \& Kegan Paul

Berry, M. (1981b). Towards layers of exchange structures for directive exchanges. Network, 2, 2332.

Berry, M. (2014). Exchange structure revisited. Paper presented to research groups at the universities of Cardiff.

Boss, K., Angell, K., \& Tewell, E. (2015). The Amazing Library Race: Tracking student engagement and learning comprehension in library orientations. Journal of Information Literacy, 9(1), 1-14.

Butt, D., Fahey, R., Spinks, S., \& Yallop, C. (1995). Using functional grammar: An explorer's guide. Sydney: Macquarie University, NCELTR (National Centre for English Language Teaching and Research).

Byram, M. (2004). Genre and genre-based teaching. The Routledge Encyclopedia of Language Teaching and Learning (pp. 234-237). London: Routledge.

Carini, R. M., Kuh, G. D., \& Kelin, S. P. (2006). Student engagement and student learning: Testing the linkages. Research in Higher Education, 47(1), 1-32.

Crook, C., \& Mitchell, G. (2012). Ambience in social learning: student engagement with new designs for learning spaces. Cambridge Journal of Education 42(2), 121-139.

Dave, R. H. (1975). Psychomotor levels. In R J Armstrong (ed.) Developing and writing behavioural objectives (pp. 20-21). Tucson: Educational Innovators Press.

Day, R. (2015). Equalizing classroom participation. Journal of Asia TEFL, 12(2), 1-17.

Emilia, E. (2005). A critical genre-based approach to teaching academic writing in a tertiary EFL context in Indonesia (A dissertation). The University of Melbourne, Australia.

Emilia, E., \& Hamied, F. A. (2015). Systemic functional linguistic genre pedagogy (SFL GP) in a tertiary EFL writing context in Indonesia. TEFLIN Journal, 26(2), 155-182.

Feez, S. \& Joyce, H. (2002). Text-based syllabus design. Sydney: NCELTR, Macquarie University.

Halliday, M.A.K. \& Hassan, R. (1985). Language, context and text: A social semiotic perspective. Melbourne: Deakin University Press.

Halliday, M.A.K. (1961). Categories of the theory of grammar. Word, 17(3), 241-292.

Halliday, M.A.K. (1975). Learning how to mean: explorations in the development of language. London: Edward Arnold.

Halliday, M.A.K. (1985). Introduction to functional grammar. London: Edward Arnold.

Halliday, M.A.K. (1994). Contexts of English. In K. Carlon, K. Davidse \& B. Rudzka-Ostyn (eds.) Perspectives of English: studies in honour of Professor Emma Vorlat Peeters.

Halliday, M. A. K. (2007). Language and education. London: Continuum.
Halliday, M. A. K. (2010). Language evolving: Some systemic functional reflections on the history of meaning. Written version of plenary talk at ISFC 2010 at the University of British Columbia.

Henrie, C. R., Bodily, R. B., Manwaring, K. C., \& Graham, C. R. (2015). Exploring intensive longitudinal measures of student engagement in blended learning. International Review of Research in Open and Distributed Learning, 16(3), 131-155.

Ko, J. W., Park, S., Yu, H. S., Kim, S. J., \& Kim, D. M. (2016). The structural relationship between student engagement and learning outcomes in Korea. AsiaPacific Edu Res, 25(1), 147-157.

Krashen, S. D. (1981). Second language acquisition and second language learning. New York: Pergamon.

Krashen, S. D. (1982). Principles and practices in second language acquisition. Oxford: Pergamon.

Kratwhol, D. R., Bloom, B. S., \& Maisa, B. B. (1973). Taxonomy of educational objectives: The classification of educational goals. Handbook II: Affective domain. New York: David McKay, Co., Inc.

Kuh, G. D. (2009) What student affairs professionals need to know about student engagement. Journal of College Student Development, 50(6), 683-706.

Love, K. \& Suherdi, D. (1996). The negotiation of knowledge in an adult English as a second language classroom. Linguistics and Education, 8(3), 229-267.

Malekie, S., \& Moghaddam, M. Y. (2017). Modeling and non-modeling genre-based approach to writing argument-led introduction paragraphs: A case of English students in Iran. Journal of Language and Translation, 7(13), 13-23.

Martin, J. R. (1985). Process and text: Two aspects human semiosis. In J. D. Benson, \& W. S. Greaves, (eds) Systemic Perspectives on Discourse, Volume 1: Selected theoretical papers from the 9th Int. Systemic Workshop. Norwood, N.J.: Ablex.

Martin, J. R. (2015). Genre-based pedagogy and literacy program. A presentation in a Seminar and Workshop in the Indonesia University of Education, 4-5 April 2015.

Marzano, R. J., Marzano, J. S., \& Pickering, D. J. (2003). Classroom management that works: Research-based strategies for every teacher. Massachusetts: ASCD.

Matthiessen, C. M. I. M. (2012). Systemic functional linguistics as appliable linguistics: social accountability and critical approaches. D.E.L.T.A, 28(Especial), 435-471.

Park, D. C., Lodi-Smith, J., Drew, L., Haber, S., Hebrank, A., Bischof, G. N., \& Aamodt, W. (2013). The impact of sustained engagement on cognitive function in older adults the synapse project. Psychological Science, 25(1), 103-112.

Payaprom, S. (2012). The impact of a genre-based approach in English language teaching in an EFL 
tertiary context in Thailand (Unpublished doctoral dissertation). University of Wollonggong, Australia.

Rivera, J. D. H. (2012). Using a genre-based approach to promote oral communication in Colombian classroom. Colombia: Universidad De Cordoba.

Sinclair, J. M. \& Coulthard, R. M. (1975). Towards and analysis of discourse the English used by teachers and pupils. Oxford: Oxford University Press.

Suherdi, D. (1994). Exchange structure patterns in an adult migrant ESL classroom (Unpublished masters thesis). The University of Melbourne, Melbourne, Australia.

Suherdi, D. (2009). Classroom discourse analysis: A systemiotic approach. Bandung: Celtics Press.

Suherdi, D. (2017). English teacher education for the $21^{\text {st }}$ century Indonesia synergizing character and academic achievement. Bandung: UPI Press.

Suryati, N. (2015). Classroom interaction strategies employed by English teachers at lower secondary schools. TEFLIN Journal, 26(2), 247-264.

Tan, M., \& Hew, K. F. (2016). Incorporating meaningful gamification in a blended learning research methods class: Examining student learning, engagement, and affective outcomes. Australasian Journal of Educational Technology, 32(5), 19-34.

Trowler, V. (2010). Student engagement literature review. Lancaster: The Higher Education Academy.

Tulung, G. J. (2013). Oral discourse generated through peer-interaction while completing communicative tasks in an EFL classroom. TEFLIN Journal, 24(2), 220-237.
Utami, I. G. A. L. P., Saukah, A., Cahyono, B. Y., \& Rachmajanti, S. (2017). Levels of involvement in the English teachers' CPD (Continuous Professional Development): The degree of professional enthusiasm. Journal of Asia TEFL, 14(2), 295-325.

Van de Pol, J., Volman, M., \& Beishuizen, J. (2010). Scaffolding in teacher-student interaction: A decade of research. Educational Psychology Review, 22, 271-297.

Ventola, E. (1987). The structure of social interaction. London: Frances Pinter.

Ventola, E. (1988a). The logical relations in exchanges. In J. Benson \& W. S. Greaves (Eds.), Systemic perspectives on discourse (pp. 51-72). Norwood, NJ: Ablex.

Ventola, E. (1988b). Text analysis in operation: A multi-level approach. In R. P. Fawcett \& D. Young (Eds.), New Developments in Systemic Linguistics (pp. 67-70). London: Pinter.

Walqui, A. (2006). Scaffolding instruction for English language learners: A conceptual framework. International Journal of Bilingual Education and Bilingualism, 9(2), 159-180.

Wang, C. (2017). Two affective variables and language learners' perception of classroom interaction. Journal of Asia TEFL, 14(1), 891-872.

Yelland, N., \& Masters, J. (2007). Rethinking scaffolding in the information age. Computers \& Education, 48, 362-382.

Zhao, C., \& Kuh, G. D. (2004). Adding value: Learning communities and student engagement. Research in Higher Education, 45(2), 115-138. 